\title{
Presidential Address Commemorating Darwin
}

\section{Citation}

Browne, Janet. 2005. Presidential address commemorating Darwin. The British Journal for the History of Science 38, no. 3: 251-274.

\section{Published Version}

10.1017/S0007087405006977

\section{Permanent link}

http://nrs.harvard.edu/urn-3:HUL.InstRepos:3345924

\section{Terms of Use}

This article was downloaded from Harvard University's DASH repository, and is made available under the terms and conditions applicable to Other Posted Material, as set forth at http:// nrs.harvard.edu/urn-3:HUL.InstRepos:dash.current.terms-of-use\#LAA

\section{Share Your Story}

The Harvard community has made this article openly available.

Please share how this access benefits you. Submit a story.

Accessibility 


\title{
Presidential address Commemorating Darwin
}

\author{
JANET BROWNE*
}

\begin{abstract}
This text draws attention to former ideologies of the scientific hero in order to explore the leading features of Charles Darwin's fame, both during his lifetime and beyond. Emphasis is laid on the material record of celebrity, including popular mementoes, statues and visual images. Darwin's funeral in Westminster Abbey and the main commemorations and centenary celebrations, as well as the opening of Down House as a museum in 1929, are discussed and the changing agendas behind each event outlined. It is proposed that commonplace assumptions about Darwin's commitment to evidence, his impartiality and hard work contributed substantially to his rise to celebrity in the emerging domain of professional science in Britain.
\end{abstract}

During the last decade a growing number of historians have begun to look again at the phenomena of scientific commemoration and the cultural processes that may be involved when scientists are transformed into international icons. On the one hand, we are more conscious than ever before of social agencies in the generation of collective responses to scientific ideas. And on the other, fresh trends in interdisciplinary studies encourage us to reconsider the rhetoric of individual achievement in shaping history. Underlying these questions are issues of cultural choice, for it is always intriguing to see how some figures catch the imagination much more than others. Einstein is such a figure, of course, and his centenary year provides many occasions to explore his extraordinary hold over the public. Alan Friedman and Carol Donley's innovative study, Einstein as Myth and Muse, long ago showed the rich rewards of investigating scientific celebrity in this manner. ${ }^{1}$ Charles Darwin is surely another. By the time of his death in 1882 Darwin was one of the most celebrated - and one of the most notorious - scientists in the world.

The impact of the controversial theory of evolution by natural selection has undoubtedly provided much of the driving power of this rise to celebrity. Within ten years of publication, sixteen different editions of On the Origin of Species by Means of Natural Selection, Or The Preservation of Favoured Races in the Struggle for Life (London, 1859), were available in Britain and North America, as well as translations into German, French, Dutch, Italian, Russian and Swedish, accompanied by a plethora of reviews and important commentaries, criticisms and supporting

* Wellcome Trust Centre for the History of Medicine, 210 Euston Road, London NW1 2BE, UK.

I would like to thank Adam Wilkinson and Sharon Messenger who have helped me a great deal in getting this final version ready for publication.

1 Alan J. Friedman and Carol C. Donley, Einstein as Myth and Muse, Cambridge, 1985. 
texts. This publishing phenomenon helped turn debate over evolutionary ideas into one of the first truly international public engagements with science. ${ }^{2}$ That debate still continues nearly 150 years later. Darwinism today inflames more cultural disagreement than nearly any other scientific theory. Modern Darwinians vigorously dispute the means of adaptation, selection mechanisms, altruism, the rate of evolutionary change, the shape and meaning of the fossil record, speciation, selfish genes and sociobiology. ${ }^{3}$ Not far away lie contentious research areas concerning evolutionary psychology, the development of language, human diversity and palaeoanthropology. Forceful advocates for new forms of creationism - as represented by intelligent design, flood geology and creation science - provoke sharp theological and political debate. ${ }^{4}$ Even though it is clear in retrospect that many of the themes addressed by Darwin were not new to him or to his readers, and history confirms that the Darwinian revolution was neither a revolution nor solely due to Darwin, it is obvious that in the mind of the public he remains the leading character of the evolutionary theatre. As so often happens, one man and one book have come to represent a complete transformation in thought.

It therefore seems appropriate for historians of science to enquire into Darwin's fame as a historical phenomenon in its own right, as something that needs to be investigated, problematized and contextualized. The moment is ripe to take up a post-postmodern position that reinvestigates the category of scientific hero and engages with Darwin's life after death - the management and use of the intellectual legacy, the commemorations, the mythologizing, the biographical traditions and wider problems of reputation in science that interweave in interesting ways with major conceptual shifts in evolutionary biology and the public status of the biological sciences through the late nineteenth and the twentieth centuries. To consider Darwin's fame raises questions about the conditions that make a scientist visible in his or her own time, exposes the changing agendas that help reify certain people as symbols and seeks a basis for what might sustain that visibility today. While taking account of Bruno Latour's astute observation that the individual scientist is not a particularly useful unit of analysis, the cult of

2 Richard Freeman, The Works of Charles Darwin: An Annotated Bibliographical Handlist, 2nd edn, Folkestone, 1977. Classic accounts of the reception of Darwin's work are Alvar Ellegard, Darwin and the General Reader: The Reception of Darwin's Theory of Evolution in the British Periodical Press, 1859-1872, reprint edn with a new foreword by David L. Hull, Chicago, 1990; and Thomas F. Glick, The Comparative Reception of Darwinism, reprint edn, Chicago, 1988. More recently, see Ronald L. Numbers and John Stenhouse (eds.), Disseminating Darwinism: The Role of Place, Race, Religion and Gender, Cambridge, 1999. On Darwinian matters in general, see David Kohn (ed.), The Darwinian Heritage, Princeton, NJ, 1985; and Jon Hodge and Gregory Radick (eds.), The Cambridge Companion to Darwin, Cambridge, 2000.

3 Summarized in Andrew Brown, The Darwin Wars: The Scientific Battle for the Soul of Man, London, 1999.

4 Among many interesting texts on creationism see Edward J. Larson, Trial and Error: The American Controversy over Creation and Evolution, Oxford, 1985; Ronald L. Numbers, The Creationists, New York, 1992; Michael Ruse (ed.), But Is It Science? The Philosophical Question in the Creation/Evolution Controversy, Amherst, 1996; and Larry A. Witham, Where Darwin Meets the Bible: Creationists and Evolutionists in America, Oxford, 2002. A measured account of the history of science and religion is given by John Brooke and Geoffrey Cantor, Reconstructing Nature: The Engagement of Science and Religion, Edinburgh, 1998. 


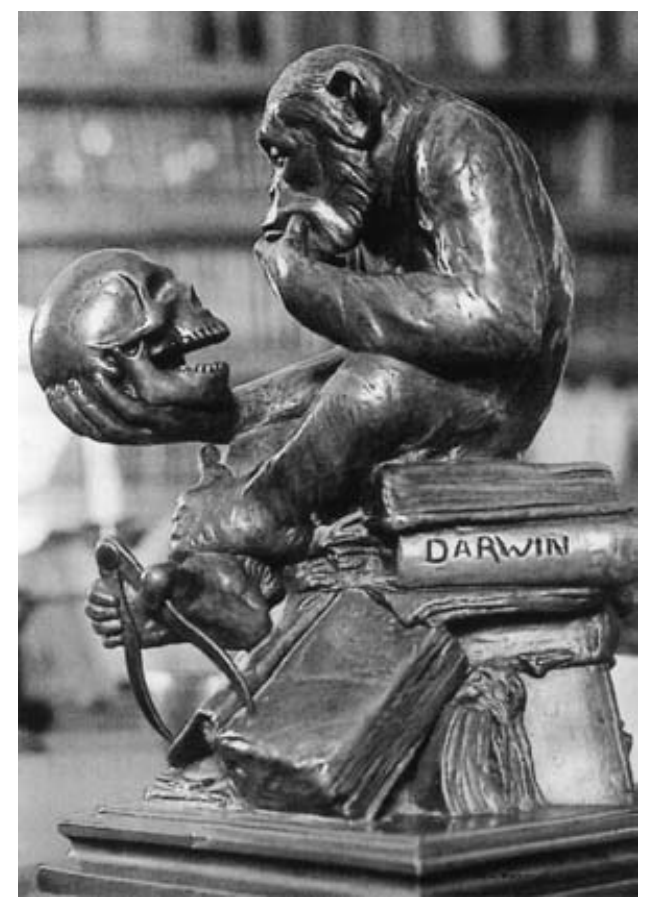

Figure 1. This pottery statuette is still fairly common. It was probably first produced in the 1880 s. It may allude to Rodin's Thinker, also produced in the 1880s. Author's collection.

heroes, nevertheless, perhaps ought not to be discarded simply as old-fashioned positivism, Whiggism or biographical opportunism. The 'great man' tradition could instead be acknowledged as a cultural feature built into the heart of the Western scientific process - a phenomenon well worth our attention. ${ }^{5}$

In this respect, towards the end of his life Darwin certainly acquired many of the attributes of a modern celebrity. ${ }^{6}$ Much of this public prominence was expressed in characteristically nineteenth-century form. Individuals could, if they wished, acquire a statuette of a chimpanzee contemplating a human skull (Figure 1). They could buy any number of inexpensive photographic cartes-de-visite featuring Darwin's portrait or caricatures that depicted him as an ape, the ancestral primate from whom it was popularly supposed that humans descended (Figure 2). Or they might pay to gape at Julia Pastrana, the 'baboon lady' or 'missing link', whose fully dressed, mummified

5 Geoff Cubitt and Allen Warren (eds.), Heroic Reputations and Exemplary Lives, Manchester, 2000. See also Naomi Oreskes, 'Objectivity or heroism? On the invisibility of women in science', in Science in the Field (ed. H. Kuklick and R. E. Kohler), Osiris (1996), 11, 87-113, 110-13.

6 This address draws on work previously published as Janet Browne, 'Charles Darwin as a celebrity', Science in Context (2003), 16, 175-94; and idem, 'Darwin in caricature: a study in the popularisation and dissemination of evolution', Proceedings of the American Philosophical Society (2001), 145, 496-509. For an overview see idem, Charles Darwin: Voyaging, New York, 1995; and idem, Charles Darwin: The Power of Place, New York, 2003. 


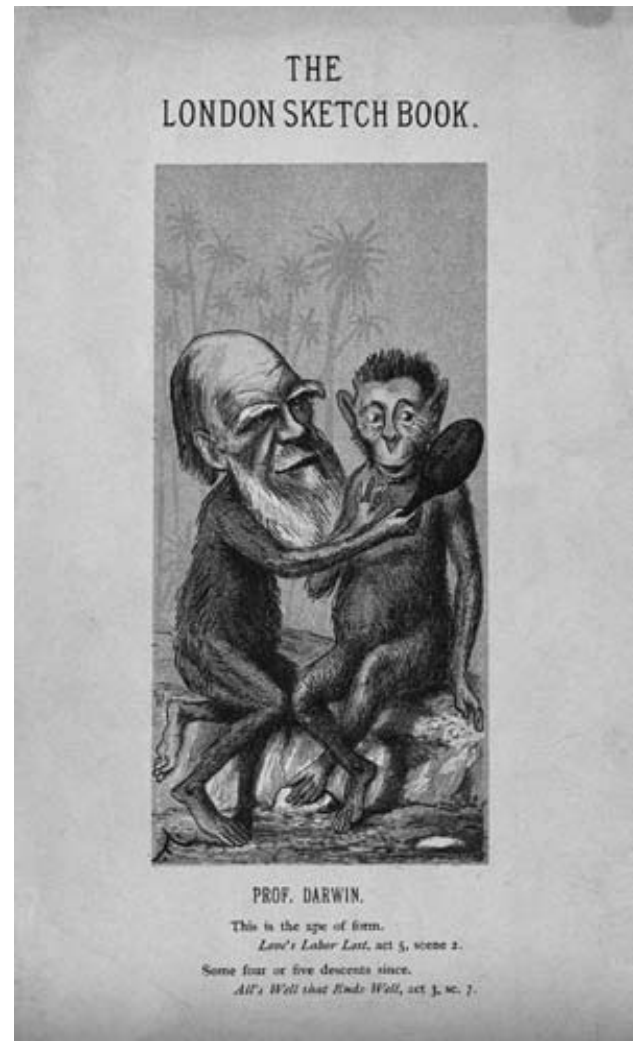

Figure 2. Victorian caricatures frequently depicted Darwin as an ape. This image appears in several different states. The original is surrounded by an elaborate woodcut cartouche accompanied by a short extract from Shakespeare, labelled Prof. Darwin, first published in Figaro's London Sketch Book of Celebrities, 18 February 1871. Courtesy Wellcome Library, London.

body toured Europe in $1862 .^{7}$ British connoisseurs were able to commission an elegant piece of Wedgwood ware decorated with the tree of life. They could sing a duet at the piano on the 'Darwinian theory', or give their children moralistic tales drawing on Darwin's achievements (Figure 3). All these commercial products made Darwin and the controversy about human origins fully tangible to his own generation and those that followed.

He is now even commoner currency. Since the biological successes of the 1950s, notably the decoding of DNA and the new turn in molecular biology, there has been a rash of Darwin buildings, centres and laboratories. There is a high-level computer programming system called Darwin, a town called Darwin, two shopping centres, a Dutch rock band (Figure 4) and a web-based virtual university named after him that opened in Northern Australia on 1 January 2004. In a BBC competition for the top ten

7 Jan Bondeson, A Cabinet of Medical Curiosities, New York, 1997. See also Janet Browne and Sharon Messenger, 'Victorian spectacle: Julia Pastrana, the bearded and hairy female', Endeavour (2003), 27, 155-9. 


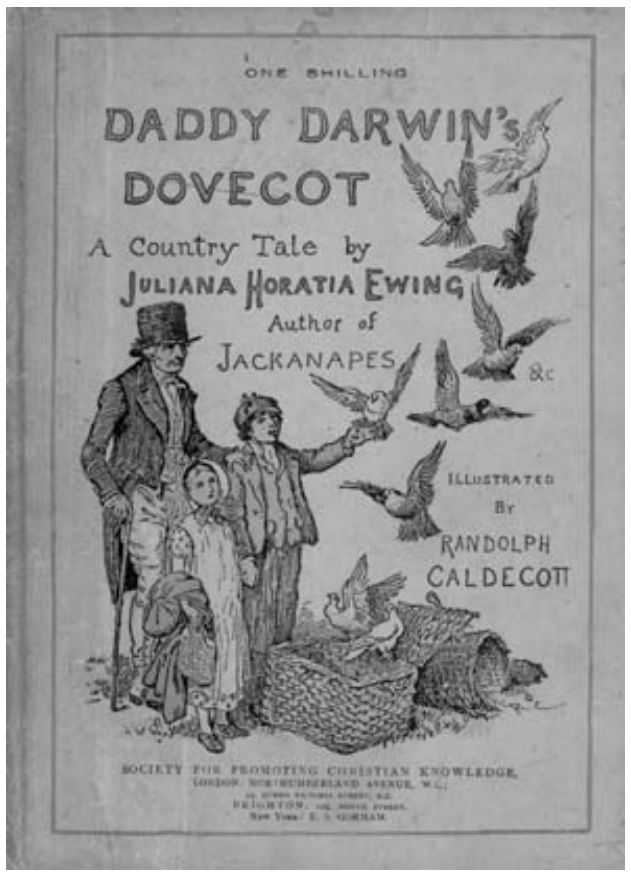

Figure 3. The illustrated cover of a children's story by Juliana Horatia Ewing, Daddy Darwin's Dovecot, London, 1884. Author's Collection.

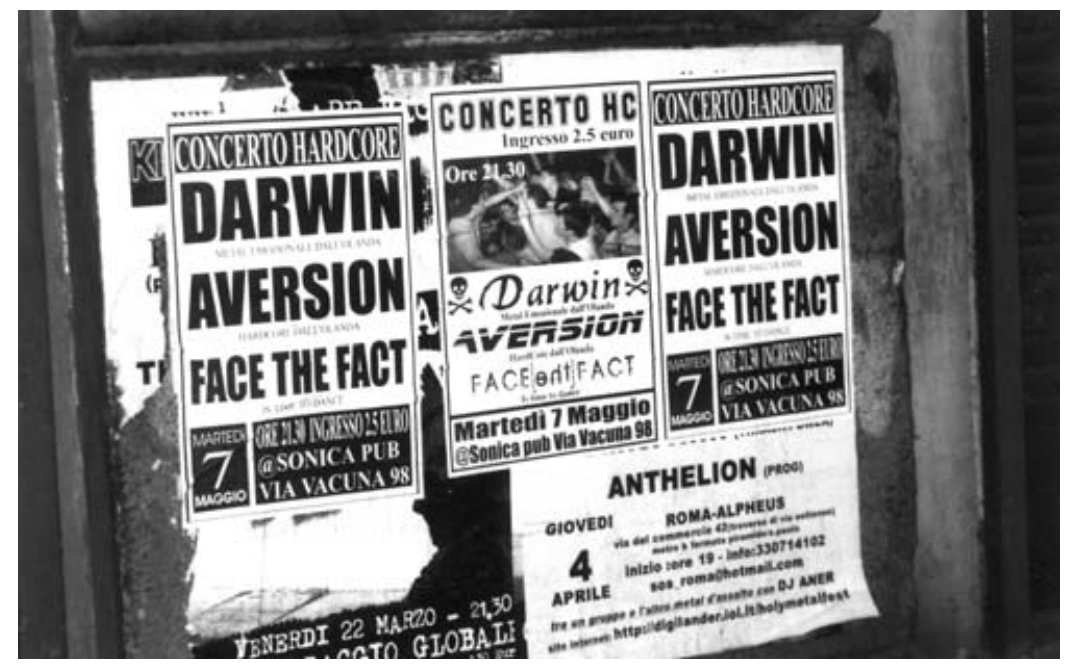

Figure 4. A Dutch rock band takes its name from Darwin. I thank Professor Vivian Nutton for this image. 


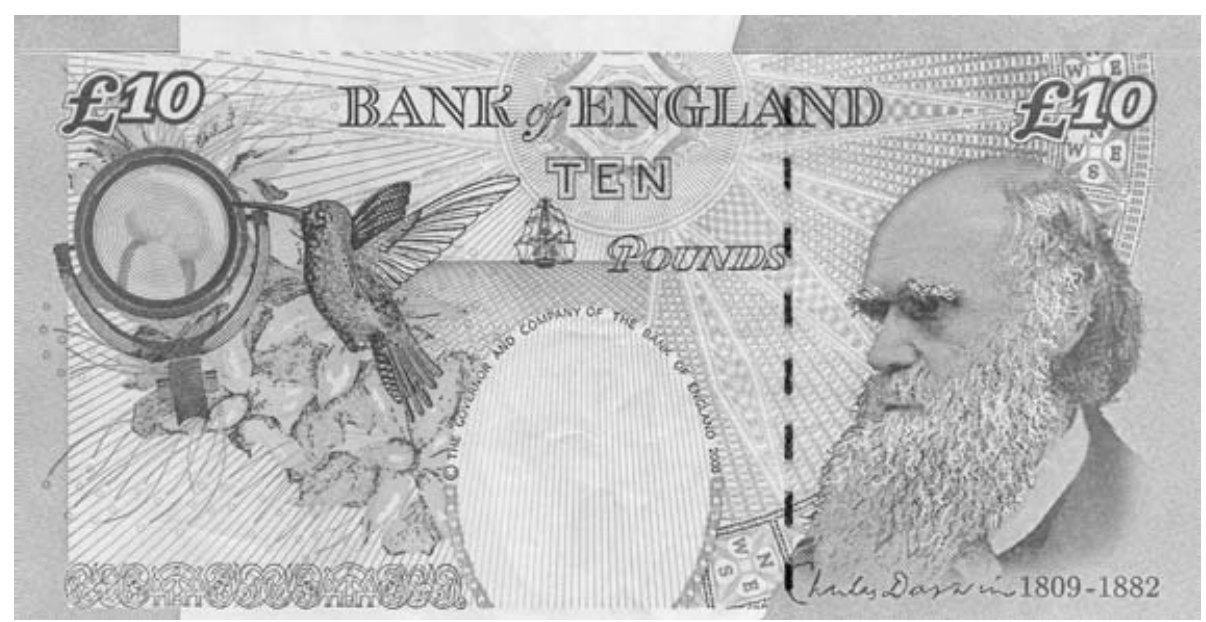

Figure 5. Darwin's portrait has been on the British ten-pound note since November 2000. Bank of England Series E $£ 10$. Photography by Adam Wilkinson.

most famous Britons, he ranked lower than Churchill but higher than Shakespeare, Nelson, Elizabeth I and Newton. He is enough of a national token for the British to meet him on the ten-pound note (Figure 5). ${ }^{8}$

In all this, Darwin is evidently being used as a label that represents something more than the man himself. From hairy ape to bearded sage, he has come to embody the ideals of independent, rational and value-free investigations into science, a commitment to pure enquiry wherever it might lead, even if it may conflict with moral, cultural, religious or ethical values. ${ }^{9}$ Buildings, banknotes or computer systems would hardly generate the same frisson if they were named after Patrick Matthew, Henry Freke or Robert Grant, let alone Lamarck, Geoffroy St Hilaire, Herbert Spencer or Robert Chambers, the other talented figures who developed ideas of evolution several years before either Darwin or Alfred Russel Wallace. ${ }^{10}$ However much we value his work, a

8 Darwin is the only scientist left. Others formerly included Isaac Newton ( $£ 1$ note, 1978-88), Michael Faraday ( $£ 20$ note, $1991-2001)$ and Christopher Wren ( $£ 50$ note, 1981-96). Information courtesy of the Bank of England.

9 Antonello La Vergata, 'Images of Darwin: a historiographic overview', in Kohn, op. cit. (2), 901-72. Some of these issues, as they relate to other figures, are addressed in Michael Shortland and Richard Yeo (eds.), Telling Lives in Science: Essays on Scientific Biography, Cambridge, 1996, especially by Geoffrey Cantor, 'The scientist as hero: public images of Michael Faraday', 171-93. See also Richard Yeo, 'Genius, method and morality: images of Newton in Britain, 1760-1860', Science in Context (1988), 2, 257-84; and the essays in Christopher Lawrence and Steven Shapin (eds.), Science Incarnate: Historical Embodiments of Natural Knowledge, Chicago, 1998. Legend-building is discussed by J. R. Moore, The Darwin Legend, Grand Rapids, MI, 1994.

10 Reflected in the revisionist scholarly work of James A. Secord, Victorian Sensation: The Extraordinary Publication, Reception, and Secret Authorship of Vestiges of the Natural History of Creation, Chicago, 2001; Pietro Corsi, The Age of Lamarck: Evolutionary Theory in France, 1790-1830, Berkeley, CA, 1988; and Adrian Desmond, The Politics of Evolution: Morphology, Medicine, and Reform in Radical London, Chicago, 1989. 
portrait of Francis Crick is not widely recognized. Peter Bowler rightly reminds us that the history of evolutionary biology is richly varied and packed full of people. ${ }^{11}$ The curiosity is this: how exactly did Darwin rise to the top?

Much of this trajectory probably took its shape from the developing cult of personality, a characteristic feature of the high Victorian period that gathered momentum over the following century. Intellectual issues aside, by the end of his publishing career Darwin was popularly regarded as the quintessence of British science, for some a secular saint, for others the epitome of wisdom, respectability and honesty, a man who cautiously and assiduously accumulated a mountain of evidence in order to overturn humanity's view of itself. Some of this imagery was directly attributable to his personal public stance. By standing aside from the controversy over evolution, for example, Darwin informally created for himself an image of scientific detachment, isolated from the common fray, impartial and gentlemanly, not that of a passionate polemicist. His image was potent. Thomas Henry Huxley, Asa Gray and Joseph Hooker, the men who took on the main defence of evolutionary theory through the post-Origin period, often referred to Darwin's credit-worthy personality in their attacks on the establishment and associated his careful impartiality with intellectual achievement and rationalism. ${ }^{12}$ Darwin was never characterized by them as a bold experimenter, as Michael Faraday might legitimately have been represented. ${ }^{13}$ Nor did Huxley call on Newtonian metaphors of a solitary explorer pushing through unknown territories of the mind. Instead, a picture of Darwin's unremitting labour and wary accumulation of fact came into sight, hand-in-hand with social responsibility, modesty, domestic serenity and an independent financial situation. This was a representation of an ideal type of Victorian scientific author that suited rising middle-class professionals with respectability on their minds, as well as providing useful ammunition for activists in their struggle for a reformulated secular agenda for British science. ${ }^{14}$ His reputation for ill-health added a dash of heroism, too. The struggle to continue with his work despite debilitating sickness indicated extraordinary dedication, at times nothing less than courage. ${ }^{15}$ By the time Descent of Man was published in 1871 reviewers were falling over themselves to congratulate

11 Peter J. Bowler, Evolution: The History of an Idea, 3rd edn, Berkeley, CA, 2003.

12 Addressed partly in Janet Browne, 'I could have retched all night: Charles Darwin and his body', in Lawrence and Shapin, op. cit. (9), 240-87. Useful models for future work in this area are S. Shapin, A Social History of Truth: Gentility, Credibility and Scientific Knowledge in Seventeenth-Century England, Chicago, 1994; and idem, 'A scholar and a gentleman: the problematic identity of the scientific practitioner in early modern England', History of Science (1991), 29, 279-327. See also Erving Goffman, The Presentation of Self in Everyday Life, reprint edn, London, 1990; Stephen Greenblatt, Renaissance Self-Fashioning from More to Shakespeare, Chicago, 1980; and M. Homans, Royal Representations: Queen Victoria and British Culture, Chicago, 1999.

13 Cantor, op. cit. (9).

14 J. B. Morrell and A. Thackray, Gentlemen of Science: Early Years of the British Association for the Advancement of Science, Oxford, 1981; Paul White, Thomas Huxley: Making the 'Man of Science', Cambridge, 2003; Ruth Barton, 'Huxley, Lubbock and half a dozen others: professionals and gentlemen in the formation of the X Club, 1851-1864', Isis (1998), 89, 410-44.

15 Browne, op. cit. (12). 
Darwin's 'unassailable integrity and candour', his 'wonderful thoroughness and honest truthfulness'.16

Many of the personal qualities attributed to Darwin in the 1870 s, the last decade of his life, also seem to have reflected more general shifts in nineteenth-century ideologies of individuality and heroism. The rhetoric of the unique and notable individual as the embodiment of national greatness that was presented early in the century by Thomas Carlyle and Ralph Waldo Emerson was being joined in the last third of the century by images of the industrious, self-made man described by Samuel Smiles. Notions of heroic inspiration and romantic genius were by then giving way to Smiles's altogether more muted coloured pictures. This might be seen as a move away from 'genius' towards 'exertion', a shift from idealized heroes like John Keats to hard workers like Anthony Trollope, from inspiration to perspiration. Stefan Collini and Anne Secord agree that Victorians around this time domesticated the concept of mental ability into a thoroughly middle-class combination of intelligence, moral rectitude and diligence. ${ }^{17}$ The same point of view was comprehensively set out for the Victorian scientific world by William Whewell, who glorified the Baconian methodologies of hard work, respectability and primacy of facts. ${ }^{18}$ Francis Galton broadly expanded and secularized the theme in the 1870s in his Hereditary Genius and English Men of Science: Their Nature and Nurture. ${ }^{19}$

In the process, older traditions of heroism were also transformed. Cubitt and Warren explain how military bravery was increasingly associated with independent, courageous deeds, often regrettable in their rashness but courageous for all that, such as the charge of the Light Brigade in the Crimea (1854) or Custer's stand at the Battle of the Little Big Horn (1876). ${ }^{20}$ Off the battlefield, acts of extraordinary individual heroism, such as Grace Darling's rescue of shipwrecked seamen in 1838, were widely applauded. In an increasingly developed world, some of the most authentic glory also seemingly came from what were perceived as fearless expeditions into the remaining heart of savagery and barbarism, such as David Livingstone's expeditions in central Africa, carried out in 1853-6 and 1858-64. ${ }^{21}$ Individuals did not even need to be present - Sir John Franklin was for many years one of the most famous of men in Britain, precisely

16 Browne, Power of Place, op. cit. (6), 351, quoting from newspaper clippings in Darwin's own collection, Cambridge University Library, DAR 129, 75, 104.

17 Anne Secord, " "Be what you would seem to be": Samuel Smiles, Thomas Edward, and the making of a working-class scientific hero', Science in Context (2003), 16, 147-73; Stefan Collini, Public Moralists: Political Thought and Intellectual Life in Britain, 1850-1930, Oxford, 1991.

18 Richard Yeo, 'An idol of the market-place: Baconianism in nineteenth-century Britain', History of Science (1985), 23, 251-98; and idem, Defining Science: William Whewell, Natural Knowledge and Public Debate in Early Victorian Britain, Cambridge, 1993.

19 Caroline Essex, 'In pursuit of genius: tracing the history of a concept in the English writings, c.1750-c. 1914', Ph.D. thesis, University College London, 2003.

20 Cubitt and Warren, op. cit. (5), 1-26.

21 John M. MacKenzie, 'The iconography of the exemplary life: the case of David Livingstone', Cubitt and Warren, op. cit. (5), 84-104. See also the forthcoming Livingstone website at the Wellcome Trust Centre for the History of Medicine at UCL developed by Christopher Lawrence, Janet Browne, Sharon Messenger, Caroline Overy and Mike Hawkins: www.livingstoneonline.ucl.ac.uk. 
because he was missing. The hermit's cave, the armed forces, the political podium, the theatre, the sporting arena, the bedroom: all these became platforms for celebrity.

Crucial to the dissemination of this kind of fame was the developing profession of journalism and changes in technologies of visual reproduction. The New York newspaper that hired H. M. Stanley to find Dr Livingstone (who was not lost) intended that Stanley should penetrate the dark places of the world, a daring feat that would be presented with a flourish to the American reader. Naturally enough, the spread of such information through a community depended very closely on the expansion of the periodical press, accompanied by increasingly diversified audiences, broadening education, improved communication networks, transformations in manufacturing and transport, and most especially on cheaper and more widely available photography, steel engravings and other graphic techniques. ${ }^{22}$ Visibility and the distribution of visual materials were key elements in the life of the famous, so much so that the Victorian world has long been acknowledged as having initiated our modern publicity machinery and as launching much of today's media-based celebrity culture. The ability to create fame was an important feature of a society committed to progress. Being able to climb the ladder of renown expressed something significant about that society's structure the existence of opportunity, perhaps, or a high estimation of personal virtue, or a cultural endorsement of determination. That a figure like Darwin could become so famous in his own day indicates the growing status of science in a community actively engaged in celebrating new forms of achievement. That he became famous for industriousness, absence from controversy and courage in facing intensely challenging religious, social and intellectual issues says a great deal about views of the scientist at that time. As a consequence, Darwin became a special kind of celebrity in the emerging domain of British professional science, fêted for his commitment to evidence and dogged hard work even by people who otherwise attacked the idea of natural selection and ape ancestry. Studies by Geoffrey Cantor, Ludmilla Jordanova, Richard Yeo, Roslynn Haynes, Patricia Fara and the late Gerry Geison make the case, in different ways, that it can be immensely valuable to enquire into former ideologies of the scientific and medical hero in order to explore exactly what kinds of achievement were most respected at various times and to draw attention to the way in which the combined desires of participants, audiences and developing means of popularization and distribution fed into the changing process of acclaim. ${ }^{23}$ An examination of Darwin's public

22 See Marina Frasca-Spada and Nick Jardine (eds.), Books and the Sciences in History, Cambridge, 2000. More general studies are Richard D. Altick, The English Common Reader: A Social History of the Mass Reading Public, 1800-1900, Chicago, 1957; and John Feather, A History of British Publishing, London, 1988. For reader response theory see U. Eco, The Role of the Reader: Explorations in the Semiotics of Texts, Bloomington, IN, 1979; for scientific readers see Secord, op. cit. (10). A useful account of the rise of illustrated texts is by J. R. Harvey, Victorian Novelists and Their Illustrators, London, 1970. See also Peter Hamilton, The Beautiful and the Damned: The Creation of Identity in Nineteenth-Century Photography, London, 2001.

23 Cantor, op. cit. (9). Ludmilla Jordanova, Defining Features: Scientific and Medical Portraits 1660-2000, London, 2000; Roslynn D. Haynes, From Faust to Strangelove: Representations of the Scientist in Western Literature, Baltimore, 1994; Gerald L. Geison, The Private Science of Louis Pasteur, Princeton, NJ, 1995; Patricia Fara, Newton: The Making of Genius, New York, 2002. 
persona surely supports their claims for a continuous, two-way interplay between individual achievement and more generalized, contextual notions of the scientific hero.

Turning to look beyond the mementoes and what Leo Braudy calls the frenzy of renown, ${ }^{24}$ there is also a luxuriant universe of post-Darwinian commemorations, biographies and iconography to be explored. For example, Pnina Abir-Am and Clark Elliot's important volume on forms of commemoration gives renewed emphasis to the way celebration can both corroborate the great-book or great-discovery model in science history and serve to control, promote or appropriate particular themes at particular moments. ${ }^{25}$ In recent exhibitions and writings, Ludmilla Jordanova has indicated the deep cultural commitments that underpin visual representations of medical and scientific figures. ${ }^{26}$ And there is much yet to be excavated from the long sweep of biographies of Darwin, some seventy in number dating from 1882 to 2004, either as mediators of memory in science or as instruments for the construction of national or disciplinary narratives. ${ }^{27}$ The afterlives of a scientist are highly revealing, no matter in what form they are manifested. Galileo had his glittering tribune in Florence, Newton his statue by Roubillac (Figure 6) and Edward Jenner his museum at the former Wellcome Historical Museum in London. Darwin first had a funeral.

Jim Moore's account of Darwin's burial in Westminster Abbey (Figure 7) provides an essential starting point for this form of scientific analysis. ${ }^{28}$ Commandeered by the Royal Society, Darwin's funeral became an occasion for national and scientific selfpromotion, a public affirmation of the prominent role of science in the late Victorian world. Darwin was known to be agnostic, was often accused of being an atheist and had indisputably dismantled the traditional biblical account of living beings, replacing divine authority with natural selection. So this was not a conventional form of veneration. The words of the ceremony emphasized Darwin's integrity, wisdom, honourable principles and gentlemanly character. His antipathy towards established religion was recast as honest doubt, the honesty of one dedicated to the pursuit of truth wherever it might lead. Headed by active scientific friends like Huxley, Galton and John Lubbock, the Royal Society thereby captured the moral high ground and consolidated the image of Darwin that had already taken shape during his lifetime as a man of wisdom and peace rather than a dangerous opponent of the Church. He had got into the Abbey through moral probity and hard work, it was implied.

24 Leo Braudy, The Frenzy of Renown: Fame and its History, New York, 1986.

25 Pnina Abir-Am and Clark A. Elliott (eds.), Commemorative Practices in Science: Historical Perspectives on the Politics of Collective Memory, Osiris (1999), 14, 1-383.

26 Jordanova, op. cit. (23). See also idem, 'Gender, generation and science: William Hunter's obstetrical atlas', in William Hunter and the Eighteenth-Century Medical World (ed. W. F. Bynum and Roy Porter), Cambridge, 1985, 385-412.

27 Frederick B. Churchill, 'Darwin and the historian', in Charles Darwin: A Commemoration (ed. R. J. Berry), London, 1982, 45-68. See also La Vergata, op. cit. (9). An analysis of Darwin scholarship is given by Ingemar Bohlin, 'Robert M. Young and Darwin historiography', Social Studies of Science (1991), 21, 597-648.

28 J. R. Moore, 'Charles Darwin lies in Westminster Abbey', in Charles Darwin: A Commemoration (ed. R. J. Berry), London, 1982, 97-113; Hannah Gay, 'No "Heathen's Corner” here: the failed campaign to memorialize Herbert Spencer in Westminster Abbey', BJHS (1998), 31, 41-54. Background information can be found in A. R. Hall, The Abbey Scientists, London, 1966. 


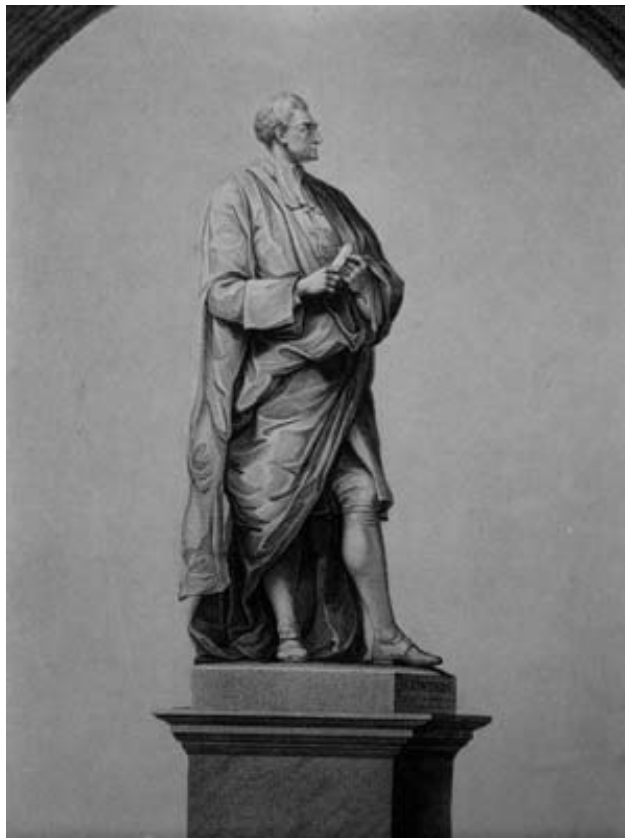

Figure 6. Isaac Newton's statue by Roubillac stands in the vestibule of Trinity College Chapel, Cambridge. Stipple engraving by J. Whessell, after Roubillac, 1755. Courtesy Wellcome Library, London.

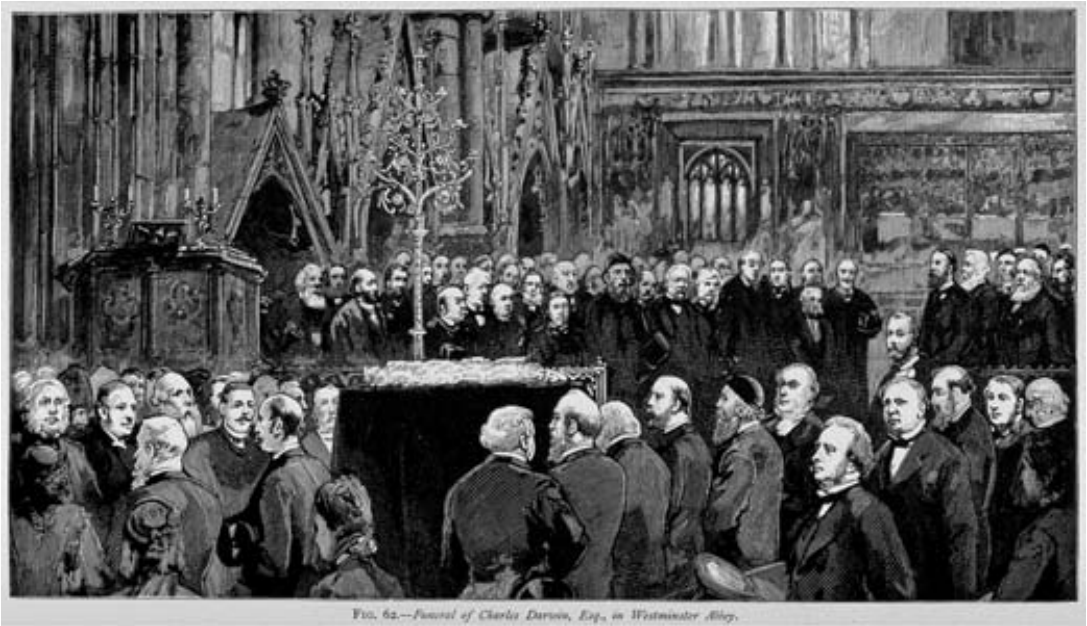

Figure 7. Darwin's funeral in Westminster Abbey, London, 26 April 1882, as depicted by Graphic, 6 May 1882, 1. Wood engraving. Courtesy Wellcome Library, London. 


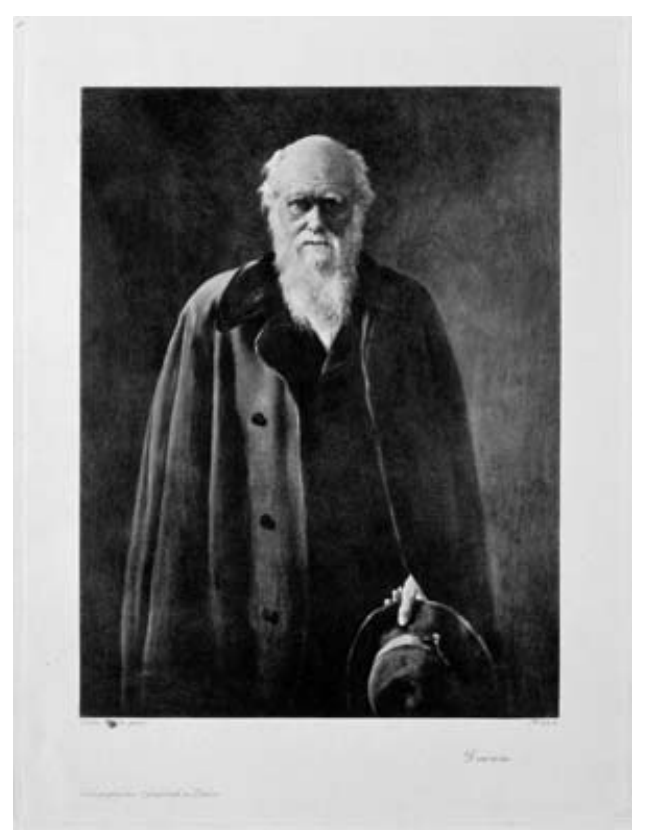

Figure 8. John Collier's oil portrait of Darwin was completed in 1881 for the Linnean Society of London. Photogravure after the Hon. John Collier, 1883. Courtesy Wellcome Library, London.

Then there was the iconography designed to impress - the portraits, photographs, sculptures, busts and plaques in various forms. ${ }^{29}$ These were all public objects of one kind or another, intended to some degree to appropriate Darwin as a famous son. Genteel civic competition between the towns of Shrewsbury, Cambridge, London, Edinburgh and Oxford emerged in the 1890s and early 1900s, each of which sought to advertise their contribution to Darwin's story. If not solely to appropriate or celebrate, these objectives were at the very least intended to demonstrate the vitality of the various subscribing bodies, as seen in the activities of the Linnean Society of London, the Shrewsbury Horticultural Society or the Royal Society. The Linnean Society's oil portrait of Darwin by John Collier (Figure 8) was commissioned in 1881, while Darwin was still alive, to mark the reading of the Darwin-Wallace papers in the Society's rooms in 1858 , the first announcement of evolution by natural selection. John Lubbock, Darwin's close friend and neighbour, was at that time the President of the Linnean Society, elected in May 1881; and Darwin's favoured disciple, George Romanes, the Zoological Secretary. The Society's Fellows generously subscribed to the portrait, even though Darwin earnestly begged Romanes that he would 'not permit any touting for subscriptions ${ }^{30}$ By contrast, the Linnean Society's portrait of Wallace, which now

29 A full iconography of Charles Darwin is still lacking but a summary list has been prepared by Janet Browne, Adrian Desmond and James Moore for the Darwin entry in Oxford Dictionary of Biography, Oxford, 2004.

30 Letter to George Romanes, 27 May 1881, extract in A. T. Gage and W. T. Stearn, A Bicentenary History of the Linnean Society of London, London, 1988, 64. Also listed in F. Burkhardt and S. Smith et al. (eds.), 
hangs next to Darwin, was not painted until the end of the twentieth century. Indeed Wallace was not elected Fellow of the Linnean Society until 1893. ${ }^{31}$ After Darwin's death the portrait by Collier was copied three times for other institutions, including the Royal Society, which retrospectively felt itself responsible for displaying Darwin's national prestige but had neglected to commission a portrait during his lifetime. The painting in the National Portrait Gallery of London is a copy, commissioned from Collier by the Darwin family, and shortly thereafter bequeathed to the gallery in $1896 .^{32}$ The third version was painted in the 1920s for Sir George Buckston Browne and hangs at Down House.

The rhetoric of such commemorative art is not quite the same as written or spoken discourse, in that it is epideictic, adapted for display, and announces that this person has served his or her country and is worthy of memory. By definition, it marks the place in which others congregate in a community and perhaps functions as a vehicle for activism. ${ }^{33}$ The Collier portrait, for instance, was an image with purpose. It emphasized Darwin's sagacity, his solitude, his ordinary-ness, dressed in day clothes (no scholarly gown, no classical toga, the usual symbols of intellect and wisdom), hat in hand, ready to go for a walk. At one level, it made visual Darwin's status as an independent private gentleman. Darwin had no scientific position such as the presidency of a learned society from which to market himself. The artist was making a statement about the truthfulness that (to him) was felt to come with independent financial means; Darwin was not tied to any employer or institution that might sway his opinion. At another, more evocative, level, Collier's intention was to venerate the power of the mind. His family relationship with Huxley (he was married to Huxley's daughter Marian), and his personal secularism, no doubt encouraged him to regard Darwin as a sage. He showed Darwin as one who walked alone, who saw far further than any of his contemporaries. Darwin's eyes were the centrepiece of the painting.

The Natural History Museum in South Kensington was, however, the first to stake an obvious claim in the public heritage industry. The museum was designed and opened in 1881 under Richard Owen, the noted comparative anatomist, without any evolutionary principles in mind. It was completely non-Darwinian, possibly even anti-Darwinian, in layout and display, a Romanesque cathedral for the natural world, where the glory of God was revealed through the wonders of nature. ${ }^{34}$ After Owen's death in 1883, however, the new director, William Flower, was a keen Darwinian disciple, who quickly

A Calendar of the Correspondence of Charles Darwin, 1821-1882: With Supplement, revised edn, Cambridge, 1994, item 13178.

31 I am grateful to Gina Douglas, Librarian of the Linnean Society of London, for this information. Wallace's absence on the walls can be confirmed, so to speak, in Gage and Stearn, op. cit. (30), where he is not mentioned in the chapter on portraits and busts, 189-94. The portrait is by Roger Remington, 1998.

32 I am grateful to Matthew Bailey of the National Portrait Gallery for this information. Dr Trudy Prescott Nuding has also kindly allowed me to see her research into the Collier portraits of Darwin.

33 Ludmilla Jordanova, 'Presidential address: remembrance of science past', BJHS (2000), 33, 387-406. See also Patricia Fara, 'Faces of genius: images of Isaac Newton in eighteenth-century England', in Cubitt and Warren, op. cit. (5), 57-81, and idem, 'Isaac Newton lived here: sites of memory and scientific heritage', BJHS (2000), 33, 407-26.

34 J. W. Gruber and J. C. Thackray, Richard Owen Commemoration: Three Studies, London, 1992, and Nicolaas Rupke, Richard Owen, Victorian Naturalist, New Haven, CT, 1994. 


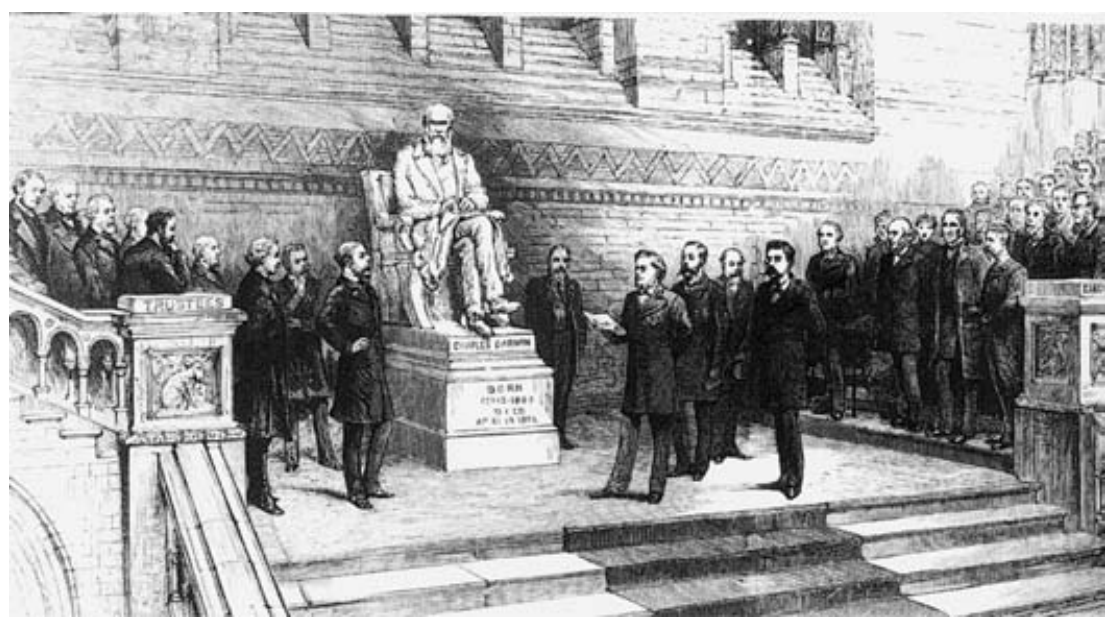

Figure 9. Joseph Boehm's statue of Darwin was unveiled by Thomas Henry Huxley in 1885. It stood in the central hall of the Natural History Museum, London. Graphic, 20 June 1885. Wood engraving. Courtesy British Library.

turned the museum into a showcase for evolution by natural selection. A magnificent marble statue of Darwin by Joseph Boehm, funded by public subscription, was commissioned. It was unveiled in 1885 in the central hall, exactly where the altar would be if this were a literal cathedral (Figures 9 and 10). The ceremony was conducted by Huxley, at that time the President of the Royal Society, still in his prime as Darwin's

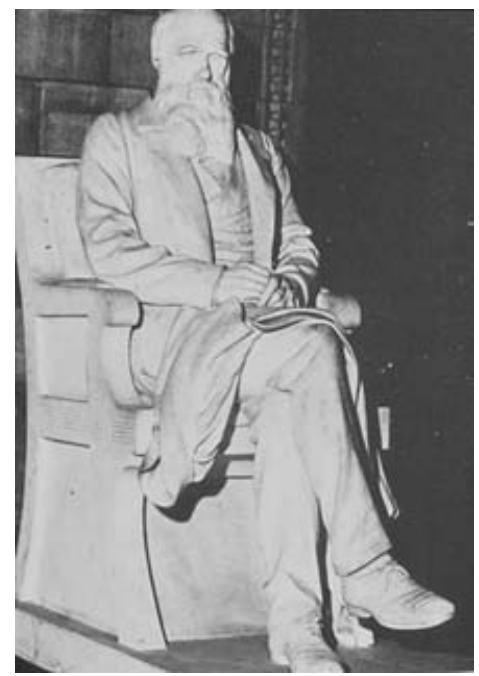

Figure 10. Boehm's statue represents Darwin in ordinary dress. Depicting him as a private individual reinforced contemporary ideas about the importance of independent financial status in science. Courtesy Natural History Museum, London. 


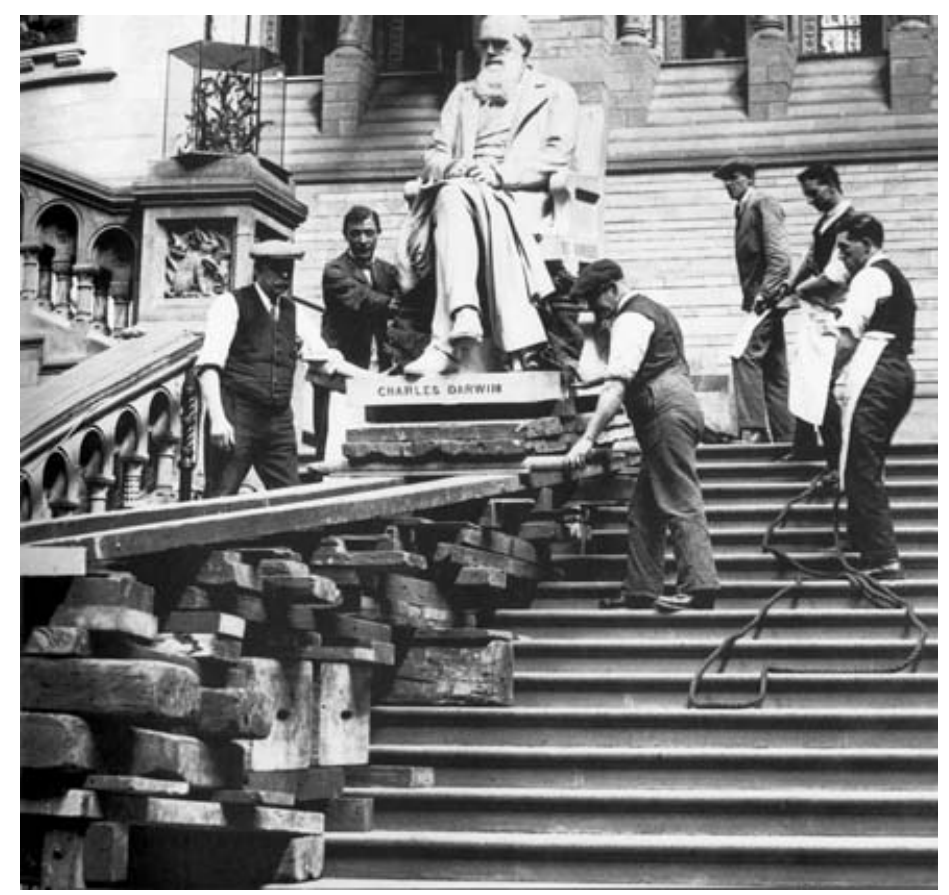

Figure 11. A newspaper photograph from September 1927 (unattributed). Courtesy Associated Press.

bulldog. But Darwin's moment in the museum soon ended. In 1927 under a modernizing new director, alert to advances in genetics and keen to disassociate the museum from mere natural history, the statue was moved (Figure 11), first to the grand hall and then to the cafeteria, where it remains, accompanied by a fine marble statue of Huxley by Edward Onslow Ford (1898). ${ }^{35}$ The two old war-horses of evolutionary theory were no longer icons of modernity. Like Collier, Boehm depicted Darwin in ordinary dress, with his outdoor coat over his knees and tiny details like shoelaces lovingly wrought, a naturalist waiting to go for a walk. The pose suggests that Boehm drew on Leonard Darwin's photograph of his father in a wicker chair on the Down House veranda, c. 1874, engraved for the Century Magazine in January 1883 and reproduced in Francis Darwin's Life and Letters of Charles Darwin in $1887 .{ }^{36}$ The eagerness of the Museum to seize and present - and in time reject - Darwin's image indicates just how keen the old order was to realign itself on a regular basis with what was regarded as the likely future. This and other learned institutions palpably regarded themselves as places of memory

35 Susan Snell and Polly Tucker, Life through a Lens: Photographs from the Natural History Museum 1880 to 1950, London, 2003. See also John C. Thackray, A Catalogue of Portraits, Paintings and Sculptures at the Natural History Museum, London, London, 1995.

36 Francis Darwin (ed.), The Life and Letters of Charles Darwin, Including an Autobiographical Chapter, 3 vols., London, 1887, ii, Frontispiece. 
and exemplars - not quite shrines, but locations that were in themselves tied to inspiration and the motivation of others. The imagery naturally moved along too.

Centenary commemorations of Darwin's birth followed in 1908 and 1909, conveniently coinciding with the fiftieth anniversary of the announcement of the theory at the Linnean Society and publication of the Origin of Species. The 1909 Darwin celebrations in Cambridge were marked by the opening of Darwin's former college rooms in Christ's College. Manuscripts were displayed, a plaque and bust by Thomas Woolner unveiled and a substantial volume of essays by noted evolutionists published. As is well known, this meeting took place when Darwinism was nearly moribund. Mutationist genetics was in the ascendant, evolutionary biometrics and statistical evolution were regarded as the mouthpiece of eugenic doctrine and teleological, directed forms of progress were generally more in favour with palaeontologists than the theory of selection by random chance as originally proposed. ${ }^{37}$ These 1909 commemorations were organized by a small group of entrenched Cambridge University naturalists and their overseas colleagues who deliberately reasserted the primacy of natural selection against its rivals. The scientific essays in the commemorative volume included work by William Bateson, Hugo de Vries and August Weissman on variation, the nature of heredity and the contested entity of the gene. ${ }^{38}$ To explore these British commemorations adds an additional dimension to the integration of chromosomal theory with hereditarian doctrine and the physical basis of the gene in the years around 1910-20.

Next came Darwin's house and garden, Down House in Kent (Figure 12). The opening of the estate as a museum in 1929 reveals something of the reification of buildings and landscapes that play such an important role in celebrity culture and in studies of the creative imagination in general. ${ }^{39}$ Perhaps, too, to some small extent, Down House participates in the larger historiographical debate over memory that focuses on the emotional meaning of sites of remembrance, from the Cenotaph in London's Whitehall to Gettysburg or Ground Zero. There is often thought to be a special resonance between writers and their places. This is particularly justified in the case of Darwin and Downe. ${ }^{40}$ At Downe he and his family were an integral part of the fabric of country life that characterized the landed classes in Britain during the middle years of the nineteenth century. It was a house, he said, on the extreme verge of the world, his safe harbour and anchor. Without this sense of physical and social place, Darwin could hardly have hoped to bring his work on natural selection to completion.

Without this sense of place, too, Darwin's work would not have taken the singular character that it did. His home and garden were his experimental laboratories, his

37 Peter J. Bowler, The Eclipse of Darwinism: Anti-Darwinian Evolution Theories in the Decades around 1900, Baltimore, 1983, and The Non-Darwinian Revolution: Reinterpreting a Historical Myth, Baltimore, 1992. I am grateful to Dr Marsha Richmond for access to her work on the 1909 celebrations.

38 A. C. Seward (ed.), Darwin and Modern Science: Essays in Commemoration of the Centenary of the Birth of Charles Darwin and of the Fiftieth Anniversary of the Publication of The Origin of Species, Cambridge, 1909.

39 Crosbie Smith and Jon Agar (eds.), Making Space for Science: Territorial Themes in the Shaping of Knowledge, Basingstoke, 1998. See also Simon Schama, Landscape and Memory, London, 1995.

40 See, for example, Michael Neve, 'Charles Darwin: Down House, Downe, Kent', in Writers and their Houses (ed. Wendy Moore), London, 1993, 151-8. 


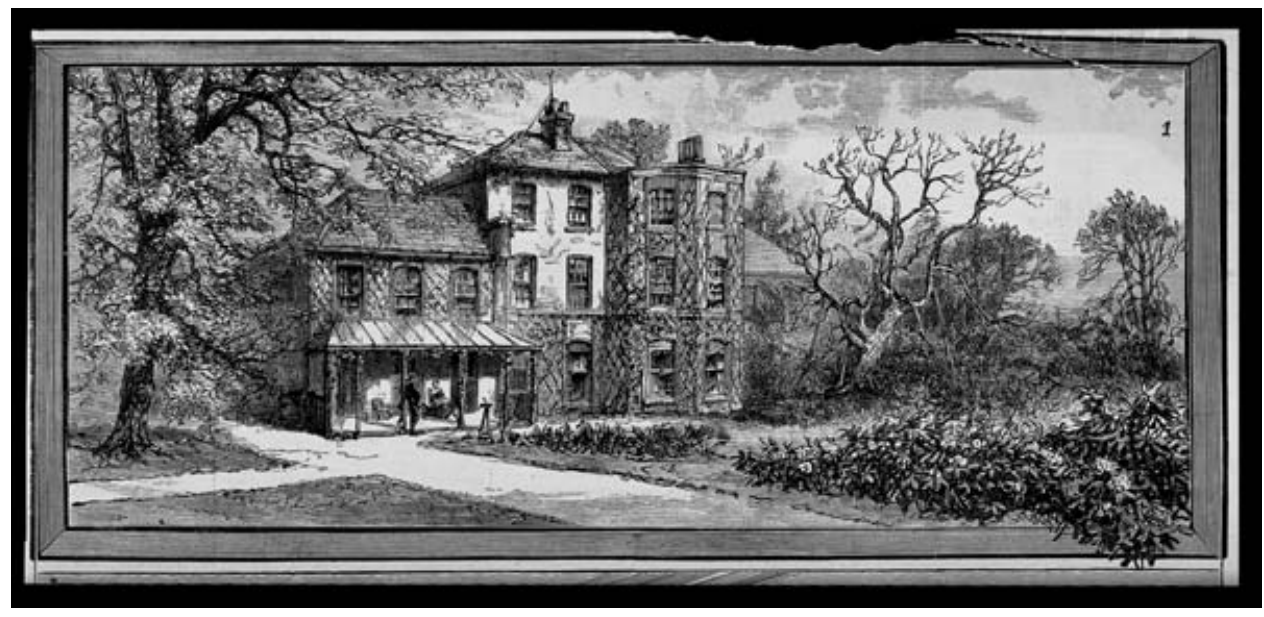

Figure 12. Down House in Kent, Darwin's home from 1842 until his death in 1882. The house was frequently visited by friends and disciples, and became closely associated in the public mind with his reputation for privacy. It remained in the family's possession until purchased for the nation by Sir George Buckston Browne in 1927. Wood engraving by J. R. Brown. Courtesy Wellcome Library, London.

book-lined study was his factory. From the first regarded as a national memorial, the reopened Down House was therefore presented as a temple to Darwin's mind and personality, as they were then perceived. It was furnished with the help of his surviving family, who re-created the old rooms as they remembered them. The sense of shrine is most obvious in his study, ostensibly unchanged since Darwin last entered the room (Figure 13). Here Darwin wrote or received some fourteen thousand letters, produced sixteen books, read reviews, persuaded scientific visitors to accept at least part of his theory, dissected barnacles, observed orchids and felt ill. It was here that private theories were transformed into public knowledge, as expressed in the Origin of Species, and then, in the years of correspondence, other writings and negotiation followed. Through the continuing publication of the Darwin correspondence by Cambridge University Press, it is becoming possible to consider Darwin at Downe as a master tactician behind the scenes, organizing his correspondents, staff, family, acquaintances and readers into a flexible, resourceful movement held together by personal commitment, publications, reviews, friendship and controversy, almost an invisible college kept alive by one man busily writing letters. ${ }^{41}$ To some degree, therefore, Darwin's study can perhaps be regarded as a centre of administration and calculation from which a transformation in Victorian thought was orchestrated. ${ }^{42}$

More than this, when the house was opened in 1929, the peaceful ambience, traditional gardens and homely furnishings may have encouraged inter-war visitors to

41 F. Burkhardt and S. Smith et al. (eds.), The Correspondence of Charles Darwin, 14 vols., 1821-66, Cambridge, 1985-2005. A synopsis of the entire correspondence is given in Burkhardt and Smith, op. cit. (30) and online at http://darwin.lib.cam.ac.uk.

42 Bruno Latour, Science in Action: How to Follow Scientists and Engineers through Society, Milton Keynes, 1987, 232-47. 


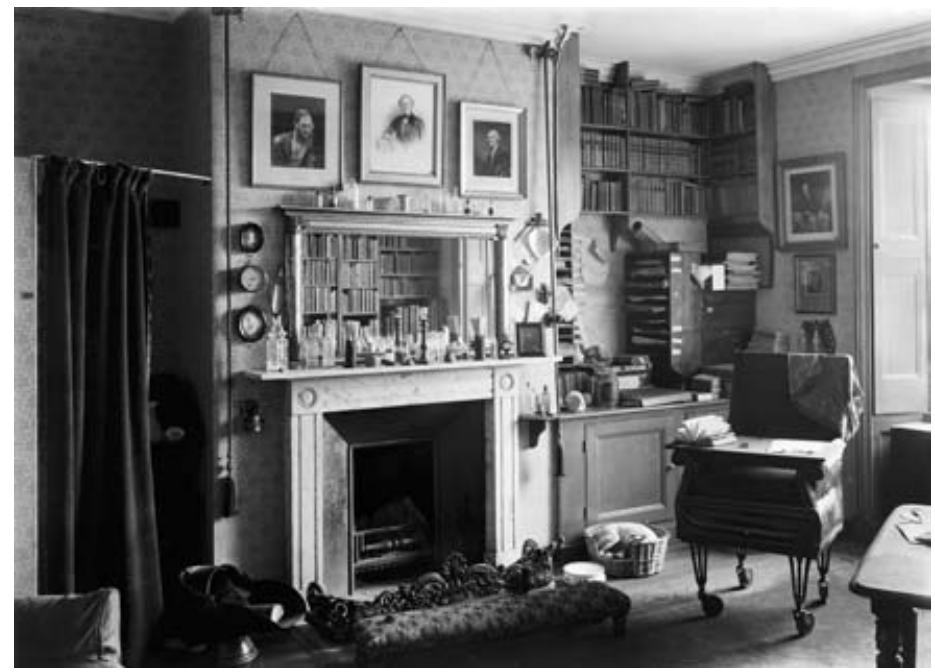

Figure 13. Darwin's study in Down House, as re-created for the opening of the house as a museum in 1929. Courtesy Wellcome Library, London.

think that world-class science did not need to be threatening or politicized. Given the widespread disillusion after the First World War, economic depression and subsequent rhetoric of regeneration through scientific progress, it looked to some as if the establishment's enthusiasm for science was not fully justified, a form of doubt most obviously brought forward in the soulless conformity, technological existence and loss of individuality expressed in Aldous Huxley's Brave New World (1932). At Down House science was humanized as patient observation, meticulous research and minimal laboratory equipment. All Darwin had needed for his great work, it might be thought, were his eyes and a pencil and paper. His working environment was encountered as a domestic space, markedly different from the fast-moving, high-powered laboratories active elsewhere in the period. The house was therefore something more than a pleasant afternoon outing for members of Lord Reith's generation. There they could expect to be educated, informed and entertained. It spoke of situated knowledge - knowledge that was domestic, comfortable, non-threatening. ${ }^{43}$

Then, in 1959, a hundred years after publication of the Origin of Species, it was the turn of the systematists, as Betty Smocovitis argues. ${ }^{44}$ In the wake of the evolutionary synthesis of the 1930s and 1940s, and Ernst Mayr's influential book Systematics and the Origin of Species (1942), the Darwin Anniversary of 1959, held in Chicago, celebrated the restoration of selection theory within a genetic and populational framework. ${ }^{45}$

43 Christopher Lawrence and Anna-K. Mayer (eds.), Regenerating England: Science, Medicine and Culture in Inter-war Britain, Amsterdam and Atlanta, GA, 2000.

44 Vassiliki Betty Smocovitis, 'The 1959 Darwin centennial celebration in America', in Abir Am and Elliott, op. cit. (25), 274-323.

45 See particularly Ernst Mayr and William B. Provine (eds.), The Evolutionary Synthesis: Perspectives on the Unification of Biology, Cambridge, MA, 1980, and Joe Cain, 'Ernst Mayr as community 
Delegates emphatically rejected Lamarckism and orthogenesis, expanded the legitimacy of Darwinian thought to cover the origin of life and the evolution of mind and cultural evolution, listened to Julian Huxley (a living heir) declare that religion was merely a behavioural function of evolving mankind and enjoyed an evolutionary musical called 'Time will Tell'. A re-enactment of the Beagle voyage took place and plans for a Darwin memorial park on the Galapágos Islands were announced. These plans meshed with international pressure on Ecuador to restrict commercial fisheries and ultimately allowed the islands to become a designated World Heritage area in $1978 .^{46}$

Curiously, the newly professionalized discipline of history of science was mostly absent. Robert Stauffer and Charles Gillispie were there in Chicago. Bernard Cohen and John C. Greene were invited but not able to go. As far as historical publications went, the focus mostly rested on surveys and collections of essays, significant in their time, one of which, Forerunners of Darwin, was initiated by the Johns Hopkins History of Ideas Club. Another 1959 collection was issued by the journal Victorian Studies. Alvar Ellegard made a careful study of the reception of Darwin's work in the British periodical press, Gertrude Himmelfarb and Loren Eisely wrote for the popular audience, John C. Greene published his innovative survey The Death of Adam, and Milton Milhauser produced Just before Darwin: Robert Chambers and Vestiges. ${ }^{47}$ There were few close evaluations of Darwin's work in historical context.

Instead the 1959 anniversary was perceived as a well-timed opportunity to retell the life story of Darwin, who was reinvented as biology's founding father, Galapágos finches and all, in a number of biographies written by scientists, including Julian Huxley (Aldous Huxley's brother), complemented by the publication of the first full transcription of Darwin's autobiography by his granddaughter Nora Barlow. ${ }^{48}$ Much of what it meant to be a twentieth-century biologist evidently hinged on identification with the narrative of Darwin's life and in seeing the continuities that led to the reconstruction of the discipline. Biologists also banded together on both sides of the Atlantic to produce commemorative volumes surveying progress in their field since Darwin's day, one group under the editorship of S. A. Barnett, another under P. R. Bell, demonstrating the same commitment to evolution by natural selection as in 1909, but now

architect: launching the Society for the Study of Evolution and the journal "Evolution",, Biology and Philosophy (1994), 9, 387-427.

46 Edward J. Larson, Evolution's Workshop: God and Science on the Galápagos Islands, New York, 2001. 47 Bentley Glass, Owsei Temkin and William Strauss, Jr (eds.), Forerunners of Darwin: 1745-1859, Baltimore, 1959; Alvar Ellegard, 'Darwin and the general reader', Gothenberg Studies in English (1958) 8, reprinted as idem, op. cit. (2); Gertrude Himmelfarb, Darwin and the Darwinian Revolution, Garden City, NY, 1959; Loren Eisely, Darwin's Century, New York, 1958; John C. Greene, The Death of Adam, Ames, IA, 1959; Milton Millhauser, Just before Darwin: Robert Chambers and Vestiges, Middletown, CT, 1959.

48 Julian S. Huxley and Henry Bernard David Kettlewell, Charles Darwin and His World, London, 1985; and Julian S. Huxley (ed.), The Living Thoughts of Darwin, Greenwich, CT, 1959. Nora Barlow (ed.), The Autobiography of Charles Darwin, 1809-1882, with Original Omissions Restored, London, 1958. See also Julian S. Huxley, Theodosius Dobzhansky, Rheinhold Niebur, Oliver L. Reiser and Swami Nikhilananda, $A$ Book that Shook the World: Anniversary Essays on Charles Darwin's Origin of Species, Pittsburg, 1958. Arthur Keith's Darwin Revalued, London, 1955, fits this category as well. Keith was a noted anthropologist and comparative anatomist at the Royal College of Surgeons, responsible in retirement as custodian of Down House. 
under happier circumstances. ${ }^{49}$ In the wider sense, too, it seems clear that these biographers - and others over the decades - presented a systematic display of consensus around key personality traits like hard work, retreat from controversy, independence of mind, commitment to evidence, courage to defy authority, lack of religious belief and so forth, in order to affirm social order in science and to tell specialized tales about the way the field should be regarded.

One small example will suffice. It appears to have been immensely important to the earliest group of biographers that Darwin's behaviour towards Alfred Russel Wallace, the co-formulator of the idea of evolution by natural selection, should be perceived as gentlemanly, that he had not taken unscrupulous advantage of a naturalist of lesser reputation and social background and that the edifice called Darwinism was untainted by any hint of possible bad behaviour by its presumed originator. It was important to show that Wallace had willingly given up his share of the credit and that this willingness was mainly due to Darwin's honourable action. The actual circumstances remain almost completely undocumented, as many have since remarked. One of the earliest biographical commentators, Arabella Buckley, a close friend and former secretary to Charles Lyell, nonetheless insisted that Lyell and Joseph Dalton Hooker 'begged' Darwin to publish his own writings alongside Wallace's. ${ }^{50}$ Edward Aveling judged Darwin's manner as 'courteously gentle, so unassuming, so frank, so graceful' ${ }^{51}$ In 1885 Grant Allen claimed that the elder naturalist 'never strove for a moment to press his own claim to priority against the younger ${ }^{32}$ These authors were all closely connected in various ways with Darwin and his intellectual legacy.

Less graciously, Samuel Butler (a writer who consciously stood outside the Darwinian movement) reminded readers about the many other men who had held roughly the same ideas as Darwin - notably Patrick Matthew, whom Darwin never properly acknowledged as a co-discoverer. ${ }^{53}$ Butler thus introduced unease about Darwin's leading place in the pantheon of science and doubts about his courtesy over intellectual debts. Perhaps this may have contributed to the ferocity with which the Darwin family responded to Butler's accusation that Darwin had stolen material from him in Darwin's Life of Erasmus Darwin, published in $1879 .{ }^{54}$ The saintly image was

49 S. A. Barnett (ed.), A Century of Darwin, Cambridge, MA, 1958, and P. R. Bell (ed.), Darwin's Biological Work: Some Aspects Reconsidered, Cambridge, 1959.

50 Arabella Buckley, A Short History of Natural Science, and of the Progress of Discovery from the Time of the Greeks to the Present Day, London, 1876, 426.

51 Edward Aveling, The Religious Views of Charles Darwin, London, 1883, 3.

52 Grant Allen, Charles Darwin, London, 1888, 81. On the page before, Allen said 'both Darwin and Wallace were born superior to the meannesses of jealousy' (ibid., 80). Obituary panegyrics are discussed in Moore, op. cit. (28), 108-10.

53 Samuel Butler, Evolution Old and New: Or, the Theories of Buffon, Dr Erasmus Darwin, and Lamarck, as Compared with that of Mr Charles Darwin, London, 1879, 315-19. See W. J. Dempster, Natural Selection and Patrick Matthew: Evolutionary Concepts in the Nineteenth Century, Edinburgh, 1983.

54 Ernst Krause, Erasmus Darwin. Translated from the German by W. S. Dallas. With a Preliminary Notice by Charles Darwin, London, 1879. For commentaries on the Butler affair see H. F. Jones, Charles Darwin and Samuel Butler: A Step towards Reconciliation, London, 1911; Philip Pauly, 'Samuel Butler and his Darwinian critics', Victorian Studies (1982), 25, 161-80; Desmond King-Hele (ed.), Charles Darwin's The Life of Erasmus Darwin, Cambridge, 2002. 
perhaps too valuable a scientific asset for Darwinians to sacrifice. In 1888, in the article on Charles Darwin in the Dictionary of National Biography, edited by their family friend Leslie Stephen, Francis Darwin declared that his father had acted with the utmost courtesy towards Wallace and that the double publication was instigated entirely by his friends Hooker and Lyell. Darwin was retrospectively absolved from any responsibility. 'The matter was left in the hands of his friends Lyell and Hooker', wrote Francis. ${ }^{\mathbf{5}}$

Anniversaries and prize-giving ceremonies, of course, are big business and have long been acknowledged as strategic events for promoting culturally significant agendas. They reveal a wish to establish collective identity on the basis of shared descent, while at the same time confining and controlling the past. Increasingly, there are substantive payoffs for historians of science, most obviously in the publication of new manuscripts, editions of letters and translations and in the production of fresh interpretations and powerful deconstructions. Less obviously, there are opportunities for advertising the strengths of our profession. The 1984 Darwin anniversary was the first in which historians were highly conspicuous. They appropriated the historical Darwin in an enormous volume, The Darwinian Heritage, skilfully brought together and edited by David Kohn, and emphatically pushed the biologists' Darwin outside the new discipline's methodological boundaries. ${ }^{56}$ But the biologists' Darwin did not die. Almost more than anyone else in the sciences, he lives on as an active presence for biologists, as evidenced by Ernst Mayr's or Stephen Jay Gould's thoughtful volumes on the nature of Darwin's achievement, or the ever-increasing run of modern popular Darwiniana on the science shelves of bookshops. Yet he is a different Darwin from the one who enters the historians' accounts - altogether less critically constructed, more inclined to be accepted at his own reading, more peaceful in the countryside. ${ }^{57}$

Looking forward to the forthcoming 2009 celebrations of Darwin's birth and the 150th anniversary of publication of On the Origin of Species, the benefit to historians is most likely to be an upturn in the availability of electronic documentary and visual resources. For biologists, though, the anniversary has the potential to do very much more. It seems very probable that the occasion will be deployed to promote the controversies of the present day, in some quarters to demonstrate the precedence of science over religion, in others to show consilience between them, and in others again the continued power of selection theory to unite the whole range of human sciences from immunology to language and the brain.

55 DNB, London, 1908, 22 vols, v, 528. While the bones of this incident have hardly changed over the years, the interpretative framework has shifted back and forth. For a pro-Wallace viewpoint see Arnold C. Brackman, A Delicate Arrangement: The Strange Case of Charles Darwin and Alfred Russel Wallace, New York, 1980. A balanced recent view is presented by Martin Fichman, An Elusive Victorian: The Evolution of Alfred Russel Wallace, Chicago, 2004.

56 Kohn, op. cit. (2), in which thirty-two scholars, predominantly European or North American, contributed articles ranging over the whole of Darwin studies, scientific and social.

57 For example the splendidly deconstructed Darwin in Adrian Desmond and James Moore, Darwin, London, 1991. An important new reading of Darwin's autobiography that, inter alia, queries the smokescreen, is given by Michael Neve's Introduction in Michael Neve and Sharon Messenger (eds.), Charles Darwin: Autobiographies, London, 2002, pp. ix-xxiii. 


\section{2}

Janet Browne

It would now be inconceivable to think of any scientific commemoration without some form of historical presence, however cursory, a point that we can regard as a significant achievement for the profession. Over the years since its foundation, the British Society for the History of Science has contributed in a large way, not only in mounting a variety of meetings in which scholars energetically re-evaluate key texts, institutions, experiments and achievements, and debunk prominent figures (I think here particularly of the BSHS Lyell Symposium in 1975 which created an entirely new Charles Lyell for scholars), ${ }^{58}$ but also in supplying an annual list of anniversaries in our Newsletter. While we are not in the business of celebration for celebration's sake, we do regard that activity as an important matter for stimulating fresh analysis.

\section{Conclusions}

It would be wrong to pretend that fame and celebrity were new phenomena in the nineteenth century, or even specifically Western phenomena. Darwin was no Roman emperor or military hero. He was never immortalized as a waxwork in Madame Tussaud's. There were no articles of clothing named after him, as there were after Lord Wellington or Lord Cardigan, nor were locks of his hair preserved and then sold as romantic treasures as happened to Lord Byron. Although there is, to be sure, a bizarre whalebone walking stick, topped with a miniature ivory skull handle, purportedly once owned by Darwin, now in the Wellcome Historical Medical Collection at the Science Museum London (Figure 14). The main relics in his case are his writings: his manuscripts are revered; and his books are very expensive if they should come to auction. In his own lifetime, Darwin's was a relatively minor and specialized glory, in which he did not seek any particular intimacy with audiences through public performance or yearn for their applause. He did not manipulate images in the same way that Queen Victoria utilized the new media. Fame was not what drove him, he told his cousin William Darwin Fox, just before the Origin of Species was published. 'If I know myself, I work from a sort of instinct to try to make out truth' ${ }^{59}$ Throughout his life he was surprised and somewhat distressed when recognized by strangers.

Yet for Victorians the label 'Darwinism' stood for the whole of the evolutionary movement, as Alfred Russel Wallace tersely noted at the end of his life - an iconic label that continues to cover modern systems of thought far removed from Wallace's and Darwin's original proposals. Darwin therefore seems to illustrate the thesis that lies at the core of most celebrity analysis - that there is a richly nuanced interaction between audiences and the figure of their admiration, and between communal desires and the social structures of the time. In Darwin's case, he was associated with rising ideologies of meritocracy, assiduity and respectability and soon afterwards came to stand for the highest principles of pure scientific enquiry. These traits continue to the present day. It is very possible that the genre of scientific celebrity (if we can call it that) was as much

58 'Lyell Centenary Issue, Papers delivered at the Charles Lyell Centenary Symposium, London 1975', BJHS (1976), 9, pt 2.

59 Burkhardt and Smith, Correspondence, op. cit. (41), vii, 269 (letter to W. D. Fox, 24 (March 1859)). 
Figure 14. A whalebone walking stick with skull pommel in ivory with green glass eyes, once owned by Charles Darwin. Science Museum, London. Courtesy Wellcome Library, London.

tied to the rise of rationalism and naturalism from the seventeenth century onwards and to the long-lasting ethos of personal originality in science as it was to the emergence of multiple audiences and the technologies of display that characterized the high Victorian period. Innovations in the media, increasingly varied means of distribution, and the consolidation of new cultural groups eager to encounter science and medicine outside the academy were immensely important, as were cultural trends relating to individualism, commercialization, professionalization and increasingly secular thought, coupled with ideological shifts about the nature of celebrity itself, whether inspired romantic genius, military hero or perceptive savant. One day it might even be possible to claim that Darwin's public persona in itself materially contributed to the crafting of these new visions of respectable, morally upright science.

This presidential address has taken as a starting point the belief that the material grounds of lived experience provide an avenue of historical access extending beyond the reaches of textual evidence into the cultural and social assumptions of a variety of communities and audiences. The primary textual resources of the historian sometimes leave unrecognized the material culture, the spaces and the practices of science and medicine - the collection and interpretation of specimens, the use of experimental equipment, the design of instruments, the portraits and other visual representations, the 


\section{Janet Browne}

houses and laboratories in which people worked, the acts of homage expressed in funerals and anniversaries and the production of popular souvenirs and ephemera. Thinking of Darwin as a celebrity, as the source of consumer interest, as a figure enshrined in statuary, buildings and artworks, as an image venerated, caricatured and utilized for various purposes, restores something of this extra dimension to his history. The shape of Darwin's fame helps in understanding something more of the processes of making and circulating knowledge in all the complexities of the historical moment. 